\title{
Szívtranszplantáció vagy abláció? Tachycardia-indukálta cardiomyopathia
}

\author{
Borbély Attila, Clemens Marcell, Jenei Csaba, Daragó Andrea, Erdei Nóra, \\ Hertelendi Zita, Fülöp Tibor, Csanádi Zoltán, Édes István
}

Debreceni Egyetem, Klinikai Központ, Kardiológiai Intézet, Kardiológiai és Szívsebészeti Klinika, Debrecen

Levelezési cím: Dr. Borbély Attila, 4032 Debrecen, Móricz Zsigmond krt. 22., E-mail: borbelya@med.unideb.hu

Egy 44 éves, 1,5 éve dilatatív cardiomyopathia miatt kezelt férfi beteget elörehaladott szívelégtelenség tüneteivel, ICD-implantáció és szívtranszplantáció szükségességének megítélése céljából irányítottak klinikánk Szívelégtelenség Ambulanciájára. EKG-n magas kamrafrekvenciával járó pitvari tachycardia ábrázolódott, melyet korábban sinus tachycardiának véleményeztek. A ritmuszavar Holter EKG-n a nappali időszak közel 90\%-ában volt megfigyelhető. Elektrofiziológiai vizsgálat során a bal pitvari szeptum anterior részéről kiinduló fokális tachycardia igazolódott, amely gyors és lassú pályán felváltva vezetődött le. A kiindulási hely sikeres ablációján kívül „double ventricular response” jelenség miatt lassú pálya ablációt is végeztünk. A beteg utánkövetése során stabil sinusritmus és szívelégtelenség bázisterápia mellett a beteg szívelégtelenség tüneteinek teljes megszűnését és a balkamra-funkció normalizálódását tapasztaltuk.

Kulcsszavak: tachycardia-indukálta cardiomyopathia, szívelégtelenség, katéter-abláció

\section{Heart transplantation or ablation? - Tachycardia-induced cardiomyopathy - Case presentation}

A 44 year-old men, diagnosed with dilated cardiomyopathy 1.5 year ago, showing clinical signs of advanced heart failure was sent to our heart failure outpatient clinic to assess the need for ICD implantation and heart transplantation. ECG showed atrial tachycardia with high ventricular response. Holter ECG confirmed the presence of the atrial tachycardia in approximately $90 \%$ of the day. Electrophysiological examination identified the focus of the tachycardia on the anterior part of the left atria with alternating conduction via a fast and a slow pathway. Besides the successful ablation of the focus, ablation of the slow pathway was also performed due to the presence of "double ventricular response". During patient follow-up - in stable sinus rhythm and on optimal heart failure drug therapy - the symptoms of the patient were completely resolved and the left ventricular systolic function normalized.

Keywords: tachycardia-induced cardiomyopathy, heart failure, catheter ablation

\section{Bevezetés}

Az aritmia/tachycardia-indukált cardiomyopathia pitvari vagy kamrai tachyarrhythmia, vagy gyakori kamrai ektópia által okozott bal kamrai diszfunkció, amely csökkent ejekciós frakcióval (EF) járó szívelégtelenséghez vezet. A balkamra-diszfunkció az aritmia megfelelő kezelése esetén részben vagy teljesen reverzibilis.

\section{Esetismertetés}

A 44 éves férfi beteg korábbi anamnézisében nagyobb megbetegedés nem szerepelt. 2014 szeptemberében felső légúti fertőzés kapcsán a betegnél átmenetileg bokaödéma jelentkezett, amely per os kacsdiuretikum hatására megszűnt. 2014 novemberében perzisztáló száraz köhögés, fulladás, csökkent terhelhetőség, fogyás miatt a helyileg illetékes Belgyógyászati Szakrendelésen jelentkezett. Mellkasröntgenen a sinusokban folyadék, jelentősen megnagyobbodott szív ábrázolódott, parenchymás árnyék nem volt. Belgyógyász endocarditis kizárását követően tüdőembólia irányú kivizsgálást javasolt. EKG-n 161/perc frekvenciájú, reguláris keskeny QRS-tachycardia ábrázolódott, amelyet sinus tachycardiának véleményeztek (1. ábra, A). Másnap Kardiológiai Szakrendelésen készült szívultrahang- 


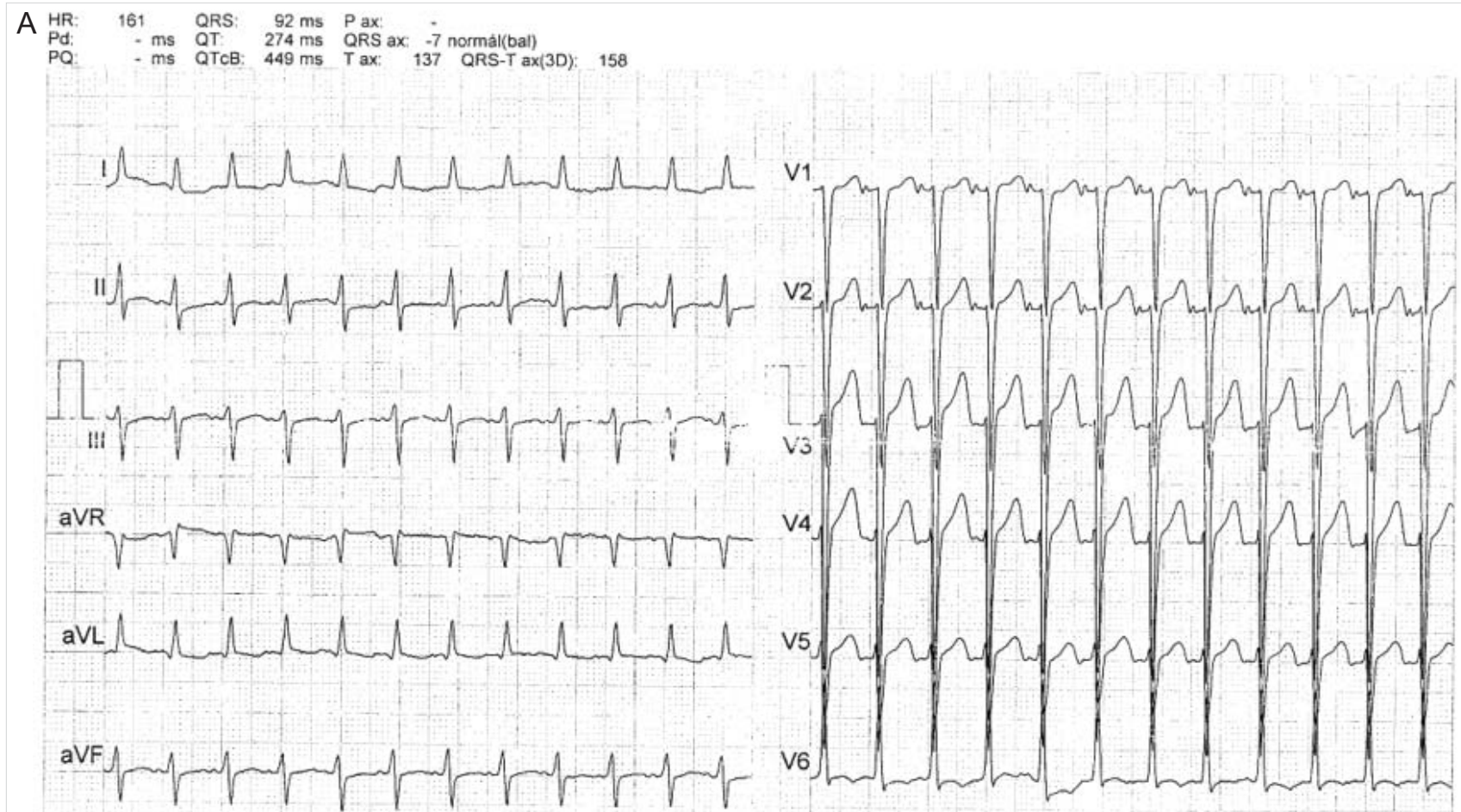

B

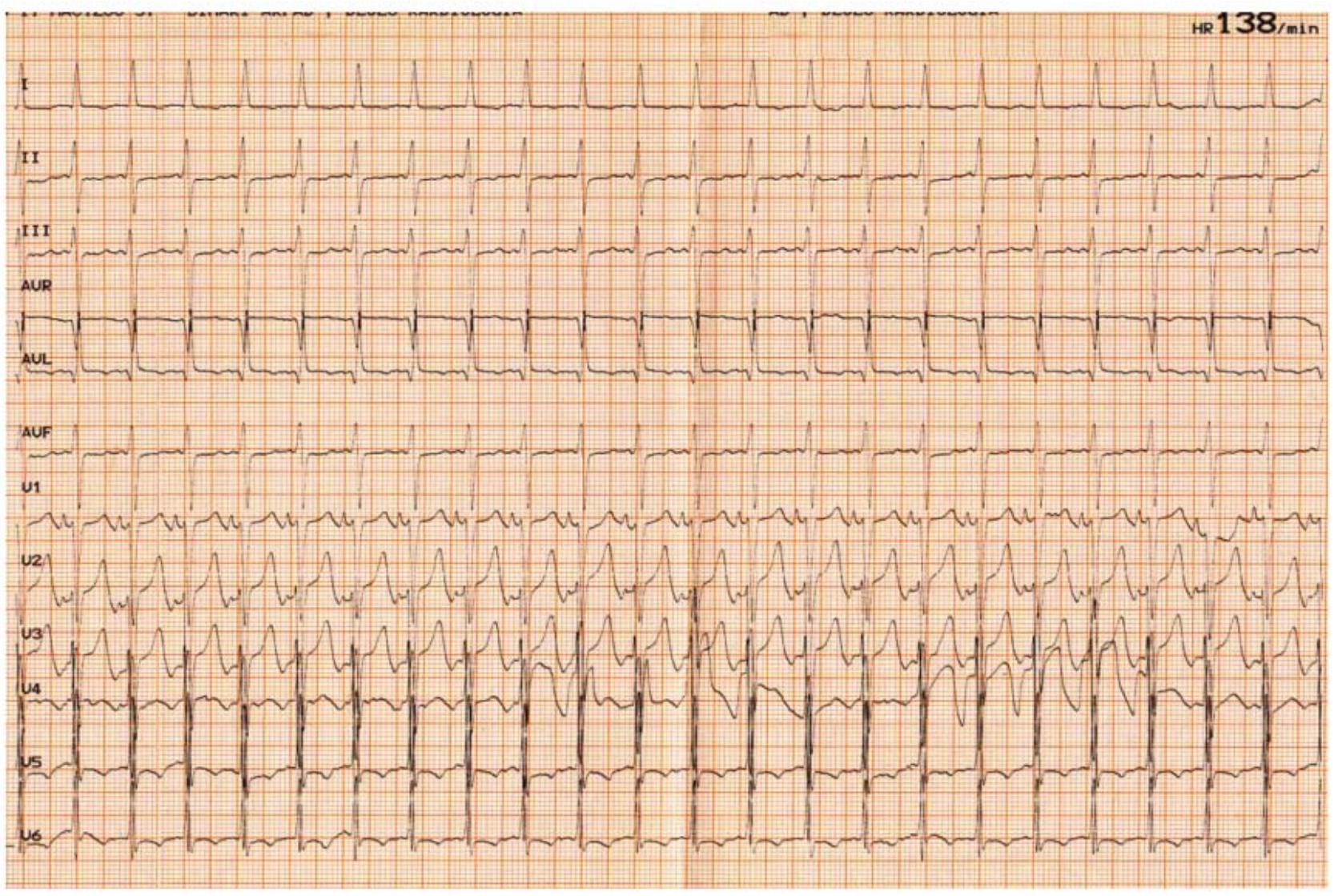

1. ÁBRA. A: A 42 éves férfi betegről 2014 novemberében a helyileg illetékes Belgyógyászati Szakrendelésen készített EKG-felvétel. 161/perc frekvenciájú reguláris keskeny QRS-tachycardia (sinus tachycardiának véleményezték). B: A betegről 2016 májusában a DE KK Szívelégtelenség Ambulancián készült EKG. 138/perc frekvenciájú pitvari tachycardia. Mindkét EKG-n a P-hullámok morfológiája eltér a sinusritmusétól: I-aVR-ben izoelektromosak, $V_{1}$-ben pozitívak 
A

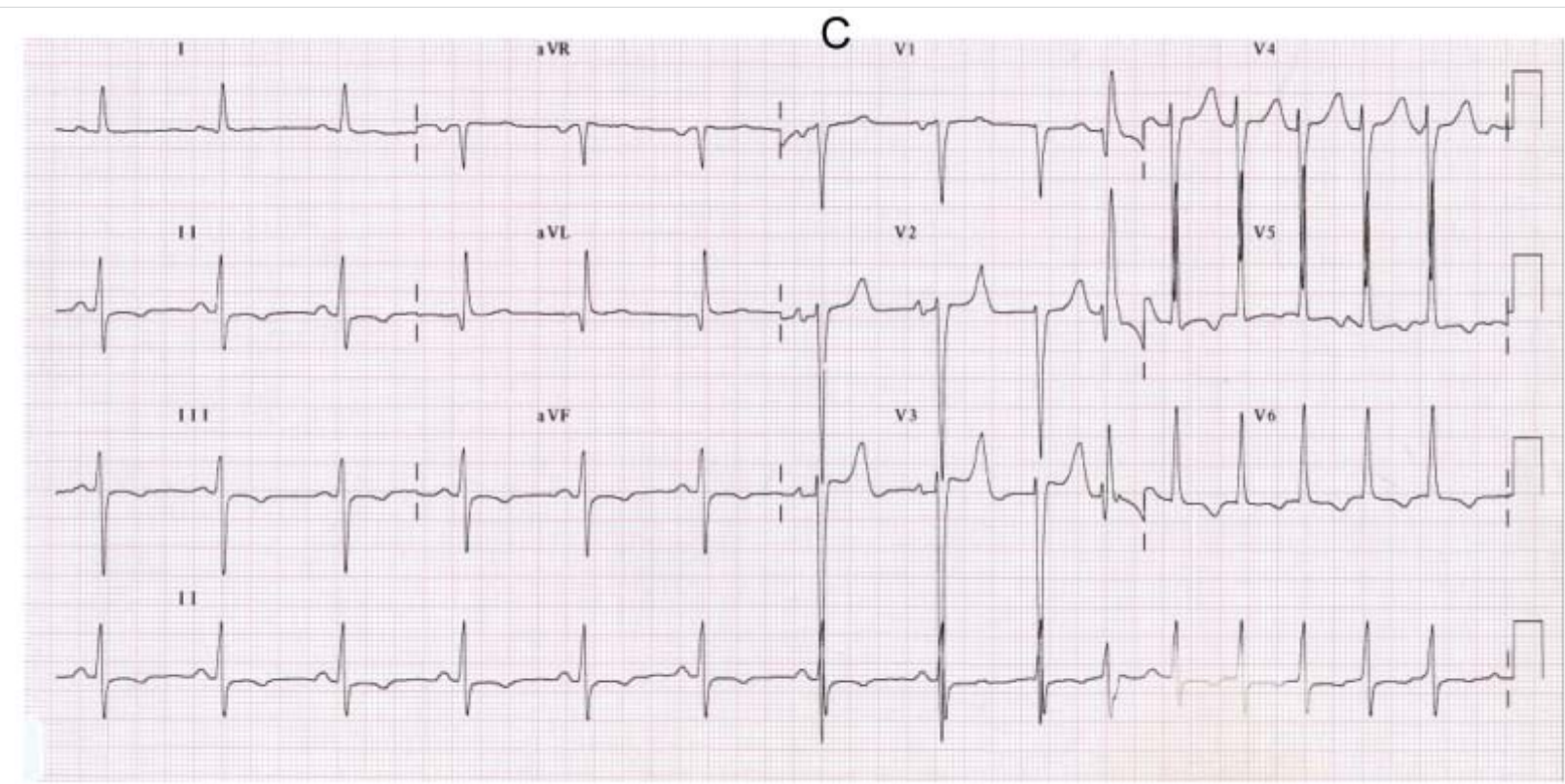

B

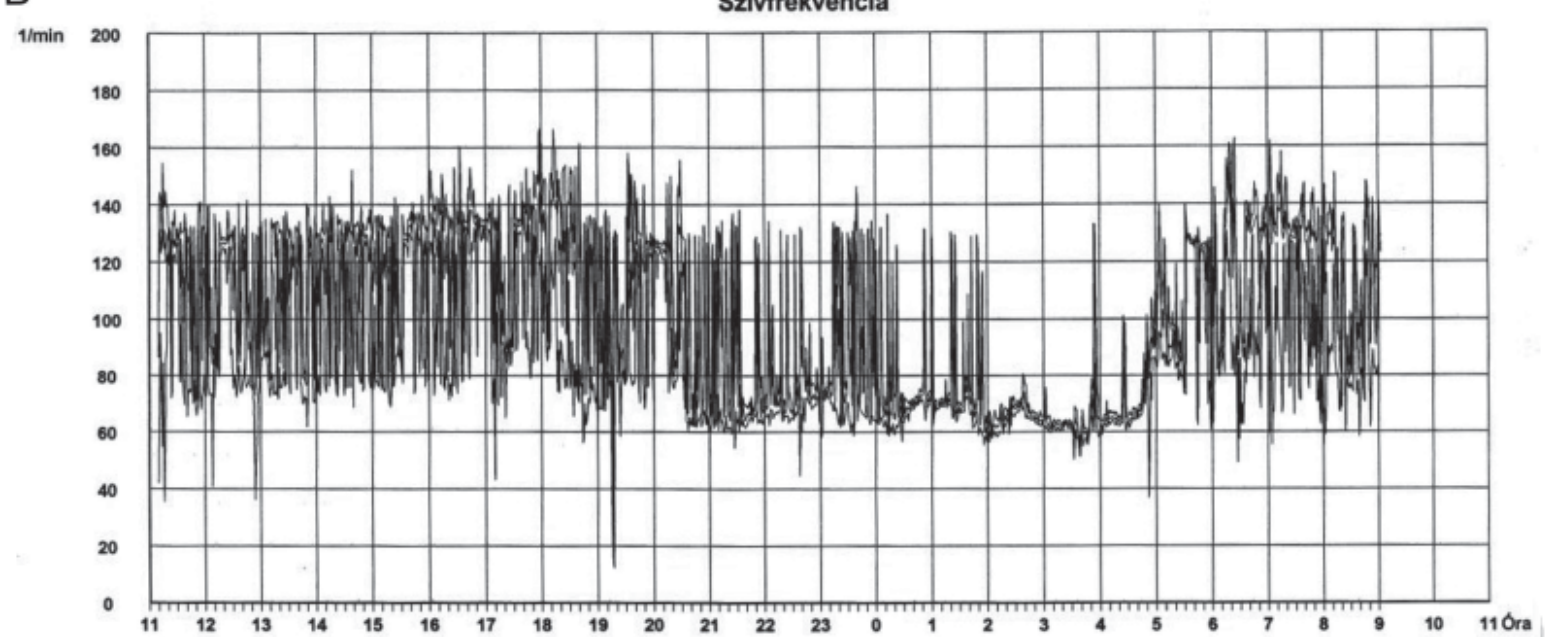

C

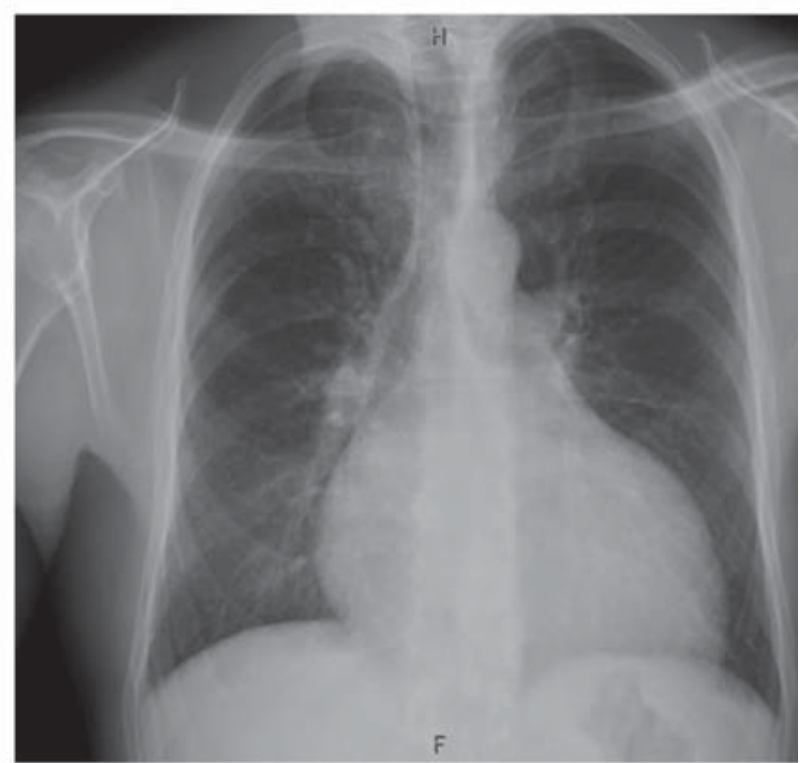

2. ÁBRA. A betegről kórházi kezelése alatt készült nyugalmi 12-elvezetéses EKG, Holter EKG és mellkas-röntgenfelvétel. A: Nyugalmi EKG-n 73/perc frekvenciájú sinusritmus és 138/perc frekvenciájú pitvari tachycardia váltakozása látható. B: Holter EKG-n a nappali időszak közel 90\%-ban pitvari tachycardia került rögzítésre. C: Mellkasröntgenen krónikus pangás jelei, vérteltebb hilusok, mindkét irányban nagyobb szív volt látható 
vizsgálat súlyos mértékben csökkent szisztolés balkamra-funkciót (EF 25\%), diffúzan hipokinetikus falmozgásokat, II. fokú mitralis regurgitációt, a bal kamrában spontán echokontrasztot, csökkent jobbkamra-funkciót igazolt, a billentyűkön vegetációra gyanús képlet nem ábrázolódott. EKG-n 120/perc frekvenciájú sinusritmust dokumentáltak. Laborokban kismértékü GGT és D-dimer-emelkedést mértek, troponin-T normáltartományban volt. Kardiológus dilatatív cardiomyopathiát véleményezett, amelynek hátterében toxikus eredetet (etil-alkohol) vagy lezajlott myocarditist feltételezett. A betegnek alkoholtilalmat, $1 \times 2,5 \mathrm{mg}$ ramipril és $2 \times 3,125$ mg carvedilol szedését, a későbbiekben a cardiomyopathia eredetének tisztázására koronarográfia elvégzését javasoltak. 1 hónappal később kontrollvizsgálat során EKG-n 100/perc frekvenciájú sinusritmus került leírásra, orális antikoagulánst indítottak, az ACE-gátló és béta-blokkoló dózisának emelését hipotónia (RR: 90/60 Hgmm) miatt nem tartották lehetségesnek. A javasolt koronária CT-vizsgálat (2015. január) kifejezett tachycardia miatt nem volt értékelhető, a beteget koronarográfiára előjegyezték.

A

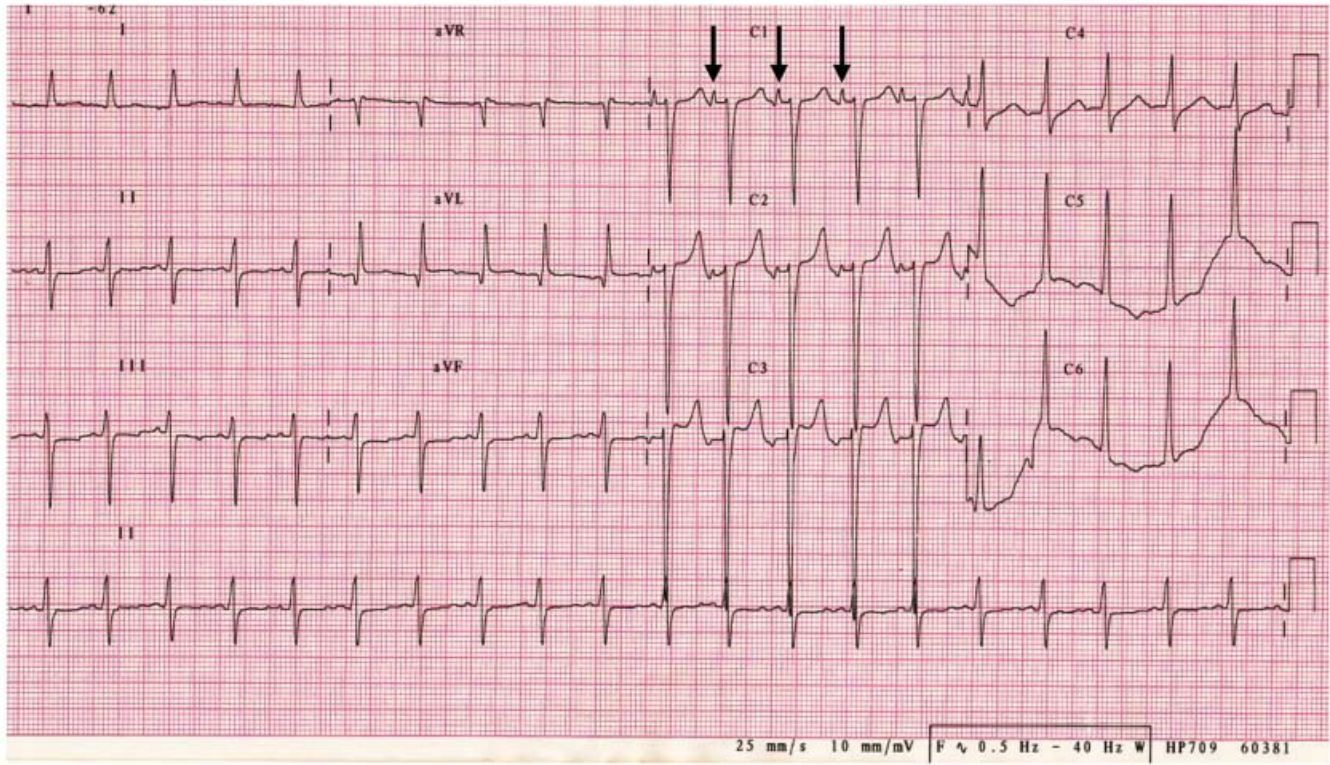

B

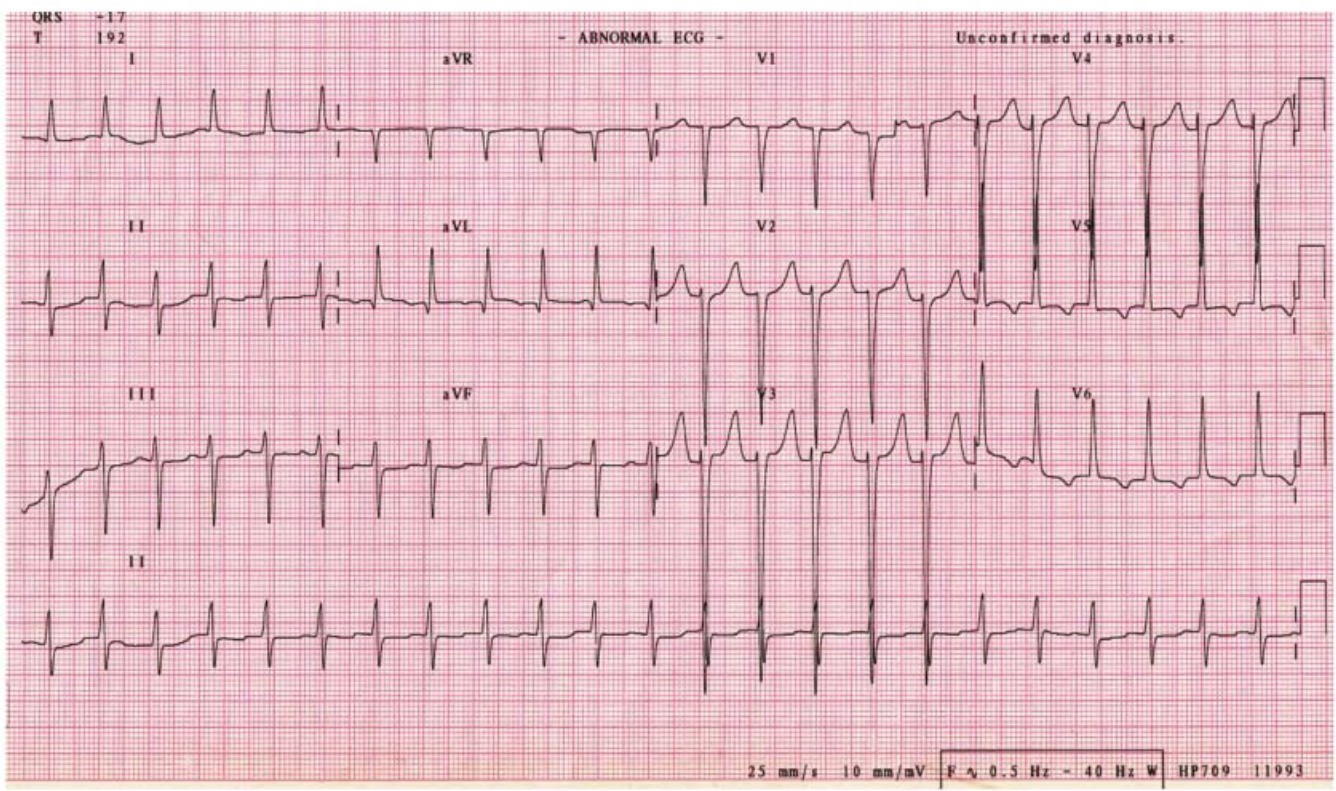

3. ÁBRA. Két különböző morfológiájú, a gyors (A) és a lassú (B) pályán levezetődő pitvari tachycardia EKG-képe. Amennyiben a ritmuszavar a lassú pályán vezetődik le, a hosszú AV-idő miatt a P-hullámok (fekete nyilak) a megelőző QRS-sel esnek egy időbe, emiatt az EKG-n nem differenciálhatók 
A

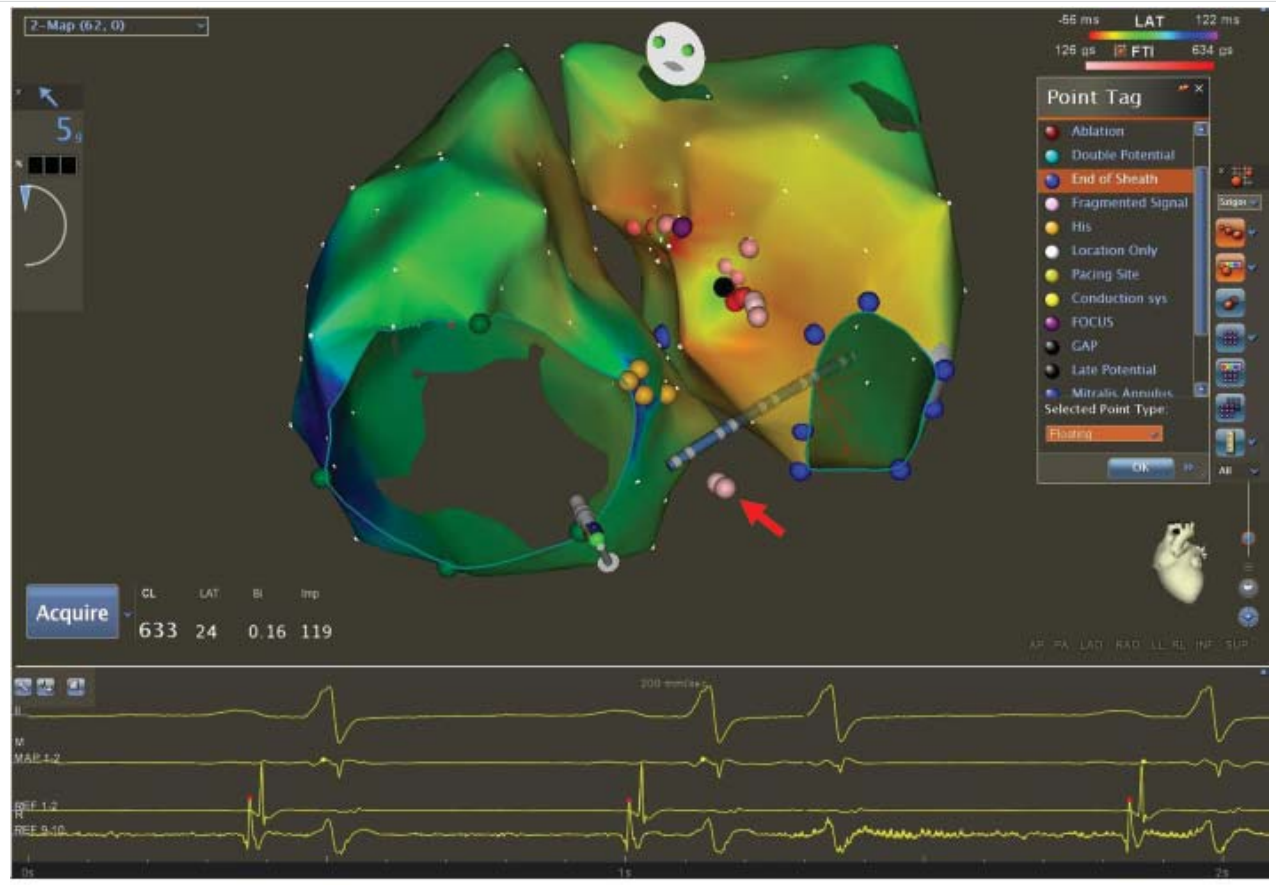

B

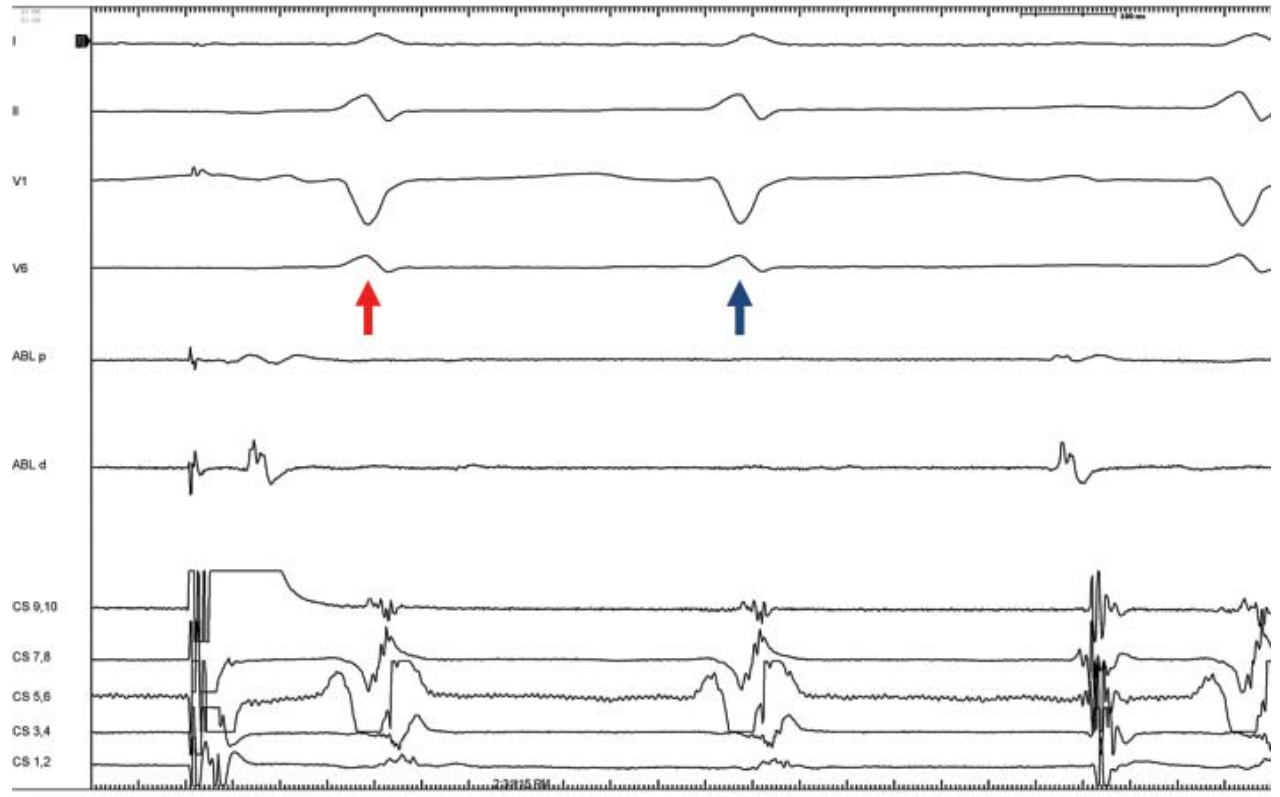

4. ÁBRA. A: Az elektrofiziológiai vizsgálat során készített jobb és bal pitvari aktivációs térképek LAO-nézetben. A piros szín a legkoraibb aktivációt jelzi (lila pont). Itt végzett két applikáció hatására a ritmuszavar nem szúnt. Tovább térképezve anterior irányban nem koraibb, de fragmentált jel volt látható, itt ablálva a ritmuszavar megszűnt (fekete pont). Itt további „bónusz” applikációkat végeztünk. Sinusritmusban „double ventricular response” jelenség volt látható (egy P-hullámot két QRS követett a gyors, majd lassú pályán levezetődve), amely miatt lassú pálya ablációt is végeztünk (a kép alján két ablációs pont, nyíllal jelölve). $B$ : Az ábrán a testfelszíni EKG-elvezetések, ablációs katéterről (ABL) és diagnosztikus sinus coronarius katéterről (CS) elvezetett intrakardiális jelek láthatók. Programozott stimuláció során „double ventricular response” jelenséget észleltünk, a pitvari extrastimulus kettős AV-csomó pályán vezetődik le a kamrákra: gyors pályavezetés (piros nyíl) és lassú pályavezetés (kék nyíl)

2015 februárjában a helyileg illetékes Kardiológiai Osztályon végzett koronarográfia során ép, jobb domináns koszorúsér-rendszer ábrázolódott. A vizsgálat közben a jobb koronária töltésekor 160/perc frekvenciájú keskeny QRS-tachycardia indult lényeges panasz nélkül (szisztolés RR: 120-130 Hgmm), amely fizikális manő- verekre nem reagált, intravénásan adott verapamil hatására sinusritmus és keskeny QRS-tachycardia váltakozása volt megfigyelhető. A carvedilol dózisát 2×6,25 mg-ra emelték, furosemidet és allopurinolt indítottak. A beteget NYHA II. funkcionális stádiumban bocsátották otthonába. 2015. március és 2016. április között a 
beteg három ambuláns kardiológiai kontrollvizsgálaton vett részt, a carvedilol dózisát $2 \times 12,5$ mg-ra növelték, további terápiamódosítás nem történt.

2016 áprilisában terhelhetőségének csökkenése, fokozódó fulladás, feszítő hasi fájdalom és puffadás miatt a beteg soron kívül jelentkezett a gondozó Kardiológiai Szakrendelésen (NYHA III-IVa funkcionális stádium).
Szívultrahang-vizsgálat a korábbiakkal gyakorlatilag megegyező balkamra-funkció (EF 32\%) mellett a mitralis és a tricuspidalis insufficientia jelentős romlását (IIIIV. fokú) és a jobb kamrai nyomás emelkedését (56+15 Hgmm) igazolta. A beteg gyógyszeres kezelését $25 \mathrm{mg}$ spironolactonnal egészítették ki, további állapotromlás esetén kórházi felvételt javasoltak.

A

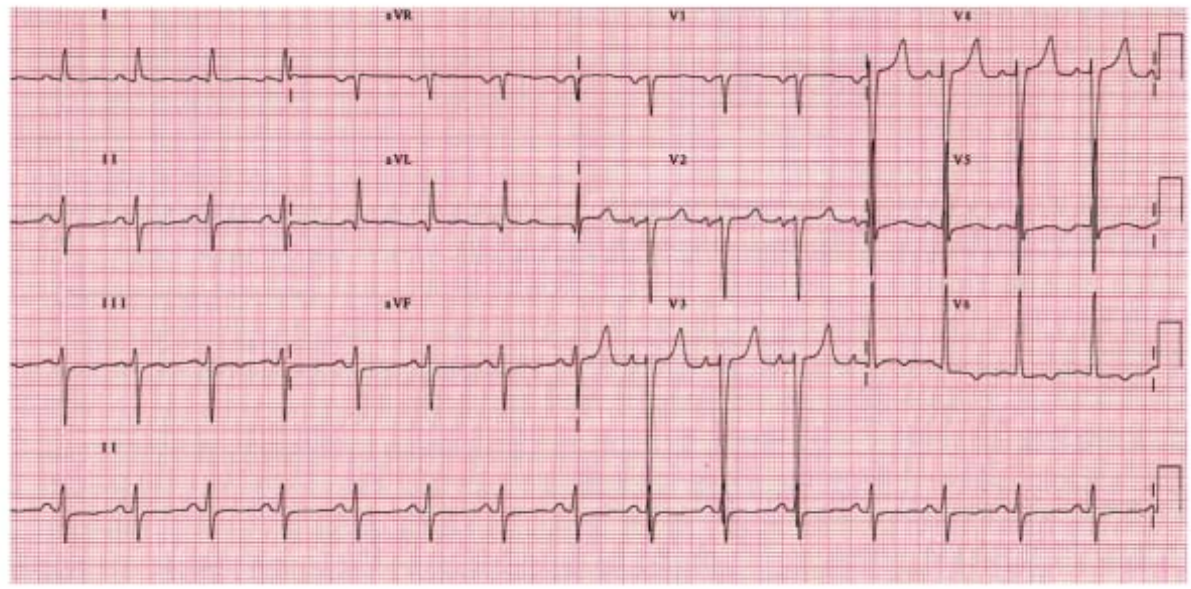

B

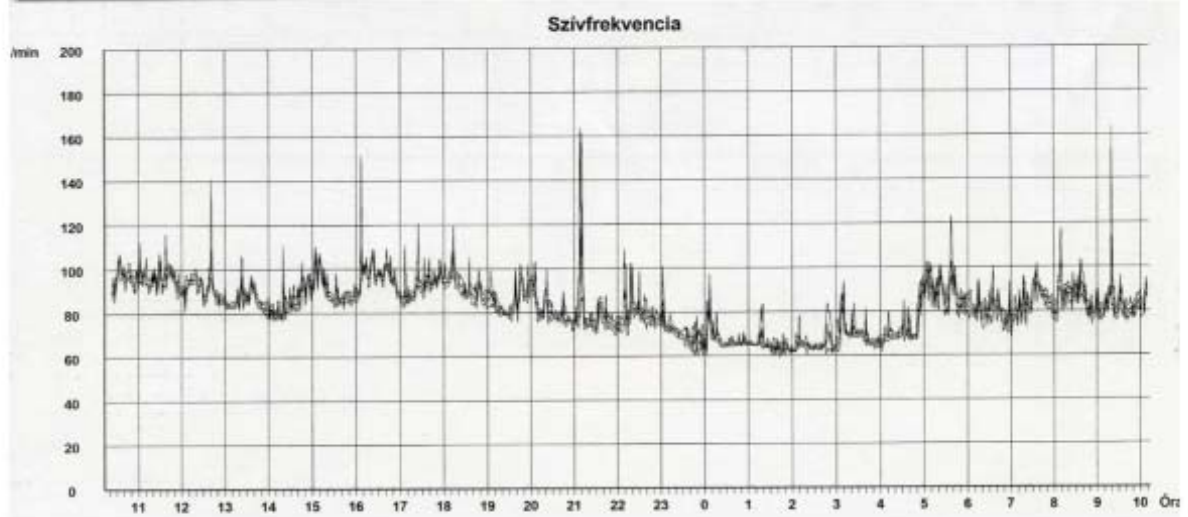

C

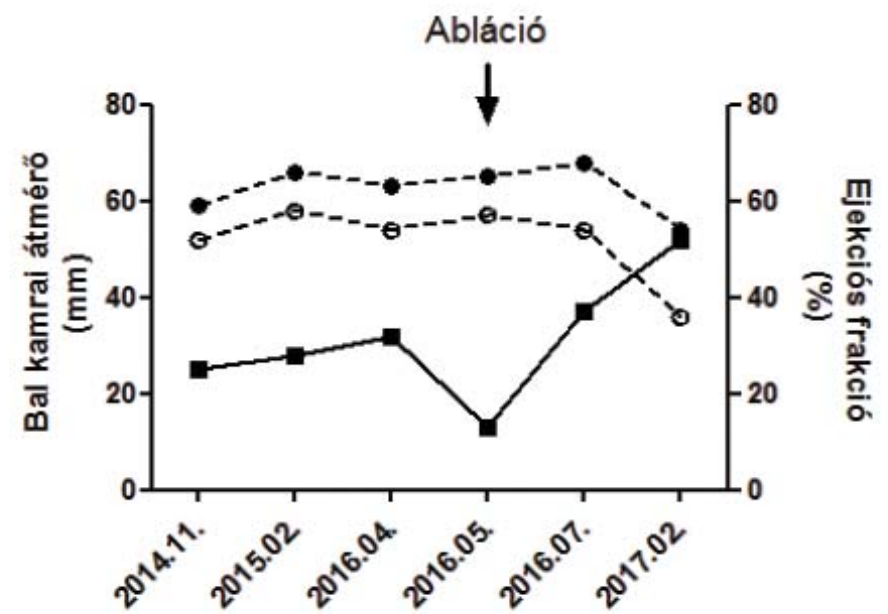

5. ÁBRA. A sikeres radiofrekvenciás abláció után végzett 12 elvezetéses (A) és Holter (B) EKG-n sinusritmus ábrázolódott, tartós pitvari tachycardia nem került rögzítésre. A bal kamrai végdiasztolés ( $\bullet$ és végszisztolés (o) átmérők, valamint az ejekciós frakció (ロ) változása a pitvari tachycardia ablációja előtt és után (C) 


\section{ICD-implantáció és szívtranszplantáció?}

2016. május végén a beteget klinikánk Szívelégtelenség Ambulanciájára irányították implantálható cardioverter defibrillátor (ICD) beültetés és szívtranszplantáció szükségességének véleményezésére. A tüdők felett apróhólyagú szörtyzörejeket, a szívcsúcson 3/6-os holoszisztolés zörejt észleltünk, bokaödéma nem volt tapintható. Szívultrahang-vizsgálat során súlyos mértékben csökkent szisztolés balkamra-funkció, (EF (Simpson) $13 \%$, verőtérfogat $18,5 \mathrm{ml}, \mathrm{dP} / \mathrm{dt}: 391 \mathrm{Hgmm} / \mathrm{sec}$ ), diffúz bal kamrai hipokinezis, II-III. fokú mitralis és III. fokú tricuspidalis insufficientia, extrém mértékben emelkedett szisztémás vaszkuláris rezisztencia $(0,6)$, tág jobb szívfél és csökkent jobbkamra-funkció került leírásra. EKG-n 138/perc frekvenciájú pitvari tachycardia ábrázolódott (1. ábra, B). A betegnek kórházi felvételt, elektrofiziológiai vizsgálatot és ablációt javasoltunk, amelyet elfogadott. Laborokban emelkedett májenzim- és húgysav-értékeket, valamint magas NT-proBNP $(5051 \mathrm{pg} / \mathrm{ml})$ szintet mértünk. Nyugalmi EKG-n sinusritmus és a pitvari tachycardia váltakozása került rögzítésre, Holter EKG-n a nappali időszak közel 90\%-ban pitvari tachycardia volt megfigyelhető (2. ábra, $A$ és $B$ ). Mellkasröntgenen krónikus pangás jelei, mindkét irányban nagyobb szív látszott (2. ábra, C). Bennfekvés alatt készített EKG-felvételeken két különböző morfológiájú pitvari tachycardiát észleltünk (3. ábra).

\section{Elektrofiziológiai vizsgálat és abláció}

Elektrofiziológiai vizsgálat során a ritmuszavar fokális pitvari tachycardiának bizonyult, amely gyors és lassú pályán felváltva vezetődött le. Zajló ritmuszavar alatt készített elektroanatómiai aktivációs térképen a legkoraibb aktivációt a bal pitvari szeptum anterior részén találtuk (4. ábra, A). Az itt leadott radiofrekvenciás applikációk alatt a ritmuszavar megszűnt és programozott stimulációval sem indult újra. A várakozási idő alatt látott „double ventricular response” jelensége (egy P-hullámot két QRS követett a gyors, majd lassú pályán levezetődve, 4. ábra, $B$ ) miatt, lassú pálya ablációt is végeztünk. A beavatkozás után végzett 12 elvezetéses és Holter EKG-n sinusritmus ábrázolódott, tartós pitvari tachycardia nem került rögzítésre (5. ábra, $A$ és $B$ ).

\section{Beteg utánkövetés}

A beteg közel két hétig tartó hospitalizációja során a szívelégtelenségterápia gyógyszereinek dózisait lépcsőzetesen feltitráltuk $(2 \times 5 \mathrm{mg}$ ramipril, $2 \times 12,5 \mathrm{mg}$ car- vedilol, $2 \times 25 \mathrm{mg}$ spironolacton, $2 \times 100 \mathrm{mg}$ ubidecarenon, $2 \times 100 \mathrm{mg}$ allopurinol, naponta $40 \mathrm{mg}$ furosemid és 600 mg káliumklorid, napi váltásban 5-7,5 mg warfarin), szimptómás hipotóniát nem észleltünk. 2016 júliusában és 2017 februárjában végzett kontrollvizsgálatok során a beteg terhelhetőségének jelentős javulásáról, fulladásos panaszainak teljes megszűnéséről számolt be, kardiopulmonálisan kompenzált, normotenziós volt (RR 120/70 Hgmm). EKG-n mindkét alkalommal sinusritmus ábrázolódott. Echokardiográfia a szisztolés és diasztolés bal kamrai átmérők csökkenését, a balkamra-funkció jelentős javulását mutatta (EF 37 , illetve $52 \%$ ) (5. ábra, C), a mitralis és tricuspidalis insufficientia mértéke nagymértékben csökkent. $\mathrm{A}$ korábban jelentősen emelkedett NT-proBNP-érték normalizálódott $(187 \mathrm{pg} /$ $\mathrm{ml}$ ). A beteg szívelégtelenségének hátterében mindezek alapján tachycardia-indukálta cardiomyopathiát véleményeztünk. Fokozottan trabekularizált bal kamra alapján felvetődött non-compact cardiomyopathia lehetősége, amely miatt a beteget szív mágneses rezonanciás (MR) vizsgálatra előjegyeztük (2017. július). Az MR-vizsgálat eredményétől függően döntünk az orális antikoaguláns további szükségességéröl, valamint információt várunk a miokardiális fibrózis mértékéről, heg(ek) jelenlétéről is.

\section{Megbeszélés}

1. Nyugalomban jelentkező $110-130 /$ perc feletti keskeny QRS-tachycardia esetén gondoljunk szupraventrikuláris (pitvari vagy junkcionális) tachycardia lehetőségére különösen, ha a látott P-hullám morfológia sem sinusritmusnak felel meg.

2. Ha a balkamra-funkció romlását aritmia/tachycardia (vagy bármilyen reverzibilis ok) okozza, akkor törekedjünk annak mihamarabbi megszüntetésére/kezelésére.

3. A szívelégtelenség bázisterápiájának feltitrálásakor a céldózisok elérését kizárólag szimptómás hipotónia, hyperkalaemia vagy a vesefunkció jelentős romlása korlátozza.

4. ICD-implantáció/szívtranszplantáció legalább 3 hónapja optimális, maximális vagy maximálisan tolerált dózisú szívelégtelenség-terápiában részesülő beteg esetében ajánlott.

Irodalom

1. Gopina thannair R, Etheridge SP, Marchlinski FE, et al. Arrhythmia-Induced Cardiomyopathies: Mechanisms, Recognition, and Management. J Am Coll Cardiol 2015; 66(15): 1714-1728. Doi 10.1016/j. acc.2015.08.038 